\title{
Construction of Banjar Women Beauty in Kalimantan Selatan Indonesia
}

\author{
Tutung Nurdiyana \\ Lecturer at Arts Performance Education Study Program, Faculty of Teacher's Training and Education Science \\ University of Lambung Mangkurat Banjarmasin, South Kalimantan \\ tutung_nurdiana@yahoo.co.id
}

\begin{abstract}
This paper describes the construction of female beauty in the Banjar community. Excavation of data is directed at information about beauty that is owned by the Banjar community. In addition, this paper also explains the shifts that have taken place around Banjar women's beauty treatments. The method used is qualitative ethnography. Beauty in Banjar women is a set of 'knowledge' possessed by Banjar women about beauty that they obtained from generation to generation and is a cultural heritage of the Banjar people. They have local knowledge in beauty treatments or Spa Banjar which is famous as 'timung'. The shift that occurs in Banjar female beauty treatments is a beauty institution, materials used in beauty care, and the concept of beauty.
\end{abstract}

Keywords: social construction; female; women's beauty

\section{Introduction}

\subsection{Background}

The Banjar community is one of the many ethnic groups in Indonesia that are located on the island of Borneo precisely in the province of South Kalimantan. Women in Banjar people pay close attention to beauty treatments. Beauty treatments by Banjar women are carried out routinely within a certain period of time according to their needs so that care beauty has become a habit and is part of the daily life of Banjar women. Beauty treatments carried out by Banjar women use many natural ingredients that are processed using traditional equipment as well as the beauty care process - also still using traditional methods as well, but there are also beauty treatments that combine with modern beauty treatments. Behavior of beautifying themselves through beauty treatments by Banjar women they manifest with Banjar Spa activities such as massage, lulur, timung, pupur and hundred (in Banjar language terms are baurut, balulur, batimung, bapupur and baratus). the famous one is timung. Timung is a traditional beauty care icon typical of Banjar people. At first timung was only used as a beauty and health care for Banjar brides. Because of the many benefits gained from timung for beauty and health, Banjar women eventually performed beauty treatments with use timung regularly for a certain period of time. The custom of Banjar women in beautifying themselves through distinctive beauty treatments gave rise to new phenomena in the business world, namely more and more emerging beauty care services in the form of beauty houses commonly called Rumah Timung. These typical Banjar beauty houses or timung houses serve a variety 
of Banjar Spas including scrubs, timung, and hundred with various variations of prices that are affordable by all circles and all economic layers of Banjar women.

Even beauty care services in the city of Banjarmasin can be called to customers' homes so they can service beauty services at home according to customer demand. Banjar beauty treatments as mentioned above that still use natural and traditional materials and equipment, also apply to the cucumber houses in the city of Banjarmasin. Although Banjar women's beauty treatments have been institutionalized in the beauty care services in the cucumber house, materials and equipment used also still use natural and traditional ingredients. In cucumber houses in general, make concoction products for each beauty treatment. So the ingredients used are ingredients for beauty treatments produced by each cucumber house. and processing materials for beauty treatments with the standard of each timung house so that each timung house has its own specialties in materials, processing and service to customers. But there are also cucumber houses that provide modern services such as creambath (rambuat treatment), manicure (hand nail care), pedicure (toe nail care), and facials (facial treatments) with more modern equipment and beauty care ingredients that are already available on the market. The beauty of Banjar women is full of dynamics and uniqueness, so this study is important to do.

It is hoped that this study will show that beauty is not a single phenomenon that has been oriented towards beauty that is often made by the media, but beauty is an ethnic phenomenon where each culture has characteristics in beautiful construction. Therefore, this study seeks to find out the construction of beauty in Banjar women along with the shifts that occur in Banjar women's beauty care.

\subsection{Problems}

This study departs from the phenomenon that Banjar women from various classes and social status pay close attention to body beauty so they routinely carry out beauty treatments within a certain period of time. Even beauty treatments performed by Banjar women still use natural and traditional materials, equipment and methods even though there are modern beauty treatments that are combined in several other types of beauty treatments. The beauty of Banjar women is a social construction built in a very long period of the journey of women's lives. As a constructed reality, beauty implies that there are facts about the development of Banjar women's awareness which are influenced by the motives, myths and social environment of the Banjar people. The formation of the meaning of Banjar female beauty occurs dynamically through various women's negotiations on various inputs to good beauty care pre modern, contemporary and post modern. To understand the development of women's awareness in the beauty and beauty meaning along with the dynamics in the formation of beauty knowledge, this study will review about:

1. How is the construction of Banjar women's beauty?

2. What changes have occurred in the care of Banjar women's beauty?

\subsection{Purpose}

There are several objectives of this research based on the formulation of the problem above. The first is to find out the construction of Banjar women's beauty, and the second is to explain the shifts that occur in the beauty care of Banjar women. 


\section{Theoretical Basis}

This study of beauty care carried out by Banjar women attempts to reveal the reality of the development of women's awareness in beauty care. For this reason, this study will use the theory of Social Construction as a theoretical perspective. The Social Construction Theory is a contemporary sociological theory coined by Peter Ludwid Berger and Thomas Luckmann.

The term social construction of reality (social construction of reality) is defined as a social process through actions and interactions where individuals create continuously a reality that is owned and experienced together subjectively (Poloma, 2003: 301). This theory will color a lot in the discussion about the reality of women and beauty in the Banjar community. The social construction theory built by Berger and Luckmann has an integrative theoretical foundation because it is heavily influenced by social theorists such as Durkheim, Weber, Marx, and Schutz. Weber contributes to Berger's thinking through interpretive understanding or analysis of understanding of the phenomena of the social world or the world of life. With Weber's interpretive understanding individual behavior as a meaningful behavior of creative individuals who do something consciously based on their rationality not only do something for structural coercion which means subjective facts. However, Berger also does not deny objective facts as stated by Durkheim who said social reality is objective (Berger and Luckman, 1990: 24). The objective reality that Berger meant was obtained through intersubjective meaning, a term given by Schultz, the foundation of phenomenology in sociology which also colored Berger's thinking.

In line with Durkeim's influence on Berger's thinking in the theory of social construction built by Berger is a theory of social action developed by a study group from Harvard University consisting of multi-disciplinary scientists namely sociology, anthropology, psychologists and biologists headed by Talcott Parson. Members of the group consisted of E. Shils and R. Merton (sociologists), C. Kluckhohn (anthropologist), H.A. Murray (psychologist). This group became one of Berger's references in strengthening social construction theory. This study group describes the process of forming social reality that cannot be separated from culture as a source of internalized values and then carried out in an action. The process of cultural formation from the level of organic systems, personality systems, social systems and cultural systems. The formation of culture through a series of processes from the process of internalization at the level of the system of organisms and personality systems then socialization in the social system and finally is enculturation (culture) in the cultural system (Koentjaraningrat, 1990: 223).

The process of cultural formation developed by Parson has inspired Berger to develop theories about the formation of social reality through three moments of social construction, namely: externalization, objectification and internalization in line with internalization, socialization and enculturation in the concepts of Parson and others. The process of forming social reality developed by Berger moves through three moments of the formation of social reality. Berger explained about social construction in three ways, namely (1) the basics of knowledge in daily life, (2) society as an objective reality, (3) society as an objective reality.

The key terms offered by Berger to understand social reality are 'reality' and 'knowledge.' 'Reality' is a quality contained in phenomena that have existence which is not dependent on the individual's will (which we cannot negate with wishful thinking. 'Knowledge' is the certainty that phenomena are real and (real) and have specific 
characteristics (Berger and Luckman, 1990: 1). Based on the two key above, Berger stated that a 'sociology of knowledge' will have to pursue not only empirical variations of 'knowledge' in human society, but also processes by which each body of knowledge is ultimately socially determined as 'reality.' In other words, the sociology of knowledge engages in social construction of reality analysis (Berger and Luckman, 1990: 4). Referring to Berger's thinking about 'reality' and 'knowledge', the beauty of Banjar women is a set of 'knowledge' possessed by Banjar women about beauty obtained by them for generations and is a cultural heritage of the Banjar people. This 'knowledge' emerged as a result of the interaction between subjective women of each Banjar about beauty and an intersubjective meaning in Banjar women. This knowledge was then used as their hold on various beauty care activities so that beauty care was ultimately a social reality. Social reality in the theoretical framework developed by Berger is a reality formed by society. Therefore, in an understanding of social construction of reality, according to Berger the understanding of social reality must first concern itself with what is "known" by the community as "reality" in everyday life that is not theoretical or theoretical. In other words, 'knowledge' common sense (commen sense), rather than 'ideas,' which must be the center of attention of the sociology of knowledge. It is precisely this 'knowledge' which is a network of meanings without which no community can live (Berger and Luckman, 1990: 22). Social reality is therefore a dialectical result of the development of knowledge of people who interact with various social and cultural aspects and the environment in which they are located. The dialectical process of the development of social reality is then understood by Berger as a momentum in the formation of social reality.

In Berger's view, social reality is formed through three momentum and he sees it as a dialectic, namely the momentum of externalization, internalization and objectification. According to him, this objective social structure has its own character but its origin must be seen in connection with human externalization or human interaction in the existing structure. This externalization then extends the institutionalization of social rules, so that structure is a continuous process, not as a solution that has been complete. Conversely, the objective reality that is formed through re-externalization forms humans in society (1990: 185). In real experience, institutions generally manifest themselves as collectivities that include large numbers of people and an institutional world, experienced as an objective reality, it has a history that precedes the birth of individuals and cannot be entered into by its biographical memory. The world has existed since he was born and will remain after he dies. History itself as a tradition of existing institutions has an objective nature. Institutions that are formed socially and become objective reality are included in one moment in the formation of social reality known as objectification. The objectification is defined by Berger as a process by which the externalized human activity products obtain objective properties. Objective is the process by which humans make various realities in their lives such as social institutions which contain values that are a common reference, terms that are understood together and language which is the youngest form of social reality captured and conveyed. These realities thus constitute a reality that becomes a product of humans that get recognition and are shared in society that binds and controls the lives of people who are members of the community (Berger and Luckmann, 1990: 85-86). What is taken for granted as knowledge in society becomes the same and similar to what is known or at least provides a framework within which everything that is not known will be known in the future. This is the knowledge gained during the socialization process and which mediates internalization into individual awareness of the 
objective social world structures. Knowledge, in this sense, is the core of the fundamental dialectic of society. He "programmed" channels where externalization produced an objective world. He manipulates this world through language and cognitive apparatus based on language; that is to say, arranging them into objects to be understood as reality. It is reinternalized as truth that is objectively applicable during the socialization. Knowledge of society, thus, is a tangible manifestation in the dual meaning of the word, namely in the sense of understanding the social reality that is objective and in the sense of continuously producing reality (Berger and Luckmann: 1990: 94-95). The reality of the beauty of Banjar women as well as the results produced by the Banjar community that automatically produces a change of the three momentum of the formation of social examples, namely externalization, objectivation and internalization. awareness of Banjar people who interact with the social and cultural realities that accompany it. Berger's social construction theory as a theory developed in this study is referred to as the main theory in this study to understand the development of women's awareness about beauty. This social construct develops along with the development of awareness that exists by the social and cultural dynamics that develop in society

\section{Methodology}

\subsection{Place}

This research has been carried out in the city of Banjarmasin from January until April 2017. Banjarmasin is used as a place of research because in this city many of the Banjar ethnic residents are active in doing beauty treatments. In this city there are also many timung houses (names for beauty treatments that use herbs and various forms of beauty treatments that use Banjar traditions).

\subsection{Time}

This research has been carried out for four months, from January to April 2017.

\subsection{Method}

Data extraction from informants was carried out using qualitative research methods. This study used ethnography with the aim of describing the phenomenon of Banjar women's beauty in more depth and emphasizing exploration of the rights or nature of the beauty phenomenon of the Banjar people through a series of unstructured data according to the community version then analyzed interpretively to produce a more comprehensive picture of the beauty of Banjar women. Through the ethnographic method, it is hoped that it will be able to open up awareness of Banjar women who are constructed by social and cultural realities that make Banjar women still routinely perform traditional beauty treatments. According to Spradley, ethnography is a job of describing culture. The purpose of this activity is to understand a view of life from the point of view of indigenous people. Spradley further stated that the essence of ethnography is an effort to pay attention to the meaning of actions from events that befall those we want to understand. Some of these meanings are expressed directly in language, and many are received and delivered only indirectly through words and deeds (1997: 3). Ethnographic methods in social research can also be used to examine certain issues that will be raised as themes so that they do not have to describe the culture of a particular society holistically. This view is expressed by Hammersley and Atkinson regarding 
ethnography. According to Hammersley and Atkinson "ethnography" is a method that has peculiarities. Ethnography consists of several research activities in the form of ethnographic participation in daily life in a long period of time, seeing what happened, hearing what they say, asking questions, in short ethnography is collecting any data that can be used to understand the issues that become research focus (1995: 1). For this purpose there were 5 informants who were purposively determined, namely the determination of informants who were considered to have knowledge about the material being studied.

Research data will be collected in several ways. The methods are as follows:

\section{Observation}

Observations or observations are made by looking at various activities of Banjar women in beauty care.

\section{Interview}

In addition to observation, data collection will also be carried out by conducting in-depth interviews (indepth interviews) using unstructured interviews with selected subjects. Interviews with this model can further explore what the informants think and feel so that, researchers are more able to reveal information from the subject's perspective and get in-depth information from the research subjects.

\section{Field notes}

Field notes are written stories about what researchers hear, see, experience, and think during the collection and reflection of data in ethnographic studies. This note will make it easier for researchers to absorb the data collection process and can reflect on what happened. From the recording process according to Bogdan, two notes will be obtained, namely: descriptive notes that present detailed events and not just a summary and reflective notes that present the mind frame, ideas, and attention of researchers (Bogdan and Biklen, 1990: 93).

\section{Data analysis}

Ethnographic research analysis comes from ethnographic records. This note is derived from the results of interviews and observations of researchers on informants. This record starts from the first contact of the researcher with the informant. All records from the beginning of the study are always analyzed to determine the direction of the next research in other words, the analysis is carried out simultaneously with the data search process in the field. Analysis of research and data collection in ethnographic research is a dialectical process (Hammersley and Atkinson: 1995: 205). Ethnographic records according to Hammersley and Atkinson were analyzed in several stages of analysis. First, find concepts related to research from the data obtained. Second, building informant typologies based on concepts built from research data. Third, discuss some research findings with previous theories related to the study theme (1995: 208-209).

\section{Results and Discussion}

\subsection{Beauty Care for Banjar Women}

Discourse about women and beauty are two things that are generally difficult to separate. Both are interrelated because when talking about women, it is definitely talking 
about beauty. As time changes, the concept of beauty changes from time to time. Reischer and Koo (2004; 297-317) define the body as a socio-cultural and historical phenomenon. The theoretical orientation used in this paper refers to theories that develop in anthropology that the body is a 'symbol' and also an agent. The symbol is an icon of social values that grow in society that can be used as a mechanism of strength and social control. The body is beautiful when it becomes an icon of social values is the result of social construction in a society at a certain time. reflect on the values or norms that develop in a society. For example, one tribe in Africa, beautiful is fat. This reflects that beautiful women are fertile women and show a symbol of prosperity with a large body (fat), and that get recognition from the community as a sexy woman. Banjar women's care behavior can be understood in Berger's frame of mind, known as social construction. Understanding the social phenomenon for Berger, similar to Schultz's thought, is directed at 'lebenswelt' or in English 'life world' or the world of life. In the tradition of phenomenological sociology 'life world' is interpreted as 'the world' or 'universe' which is small, complex and complete which consists of the physical environment, social environment and human interaction (intersubjectivity) and values that are lived (Zeitlin, 1995). However, Berger contributed to phenomenology by developing the concept of 'social construction.' In Berger and Lukman's view (1990), social reality as a reality constructed was seen as a dialectic between the internalization of internalization and objectification. Culture of Banjar women's beauty care if understood from the framework of social construction thinking, the culture of beauty care is understood as the result of social interaction between the natural environment and various cultures that exist as a source of public knowledge in beauty care. Therefore beauty care for Banjar women is an accumulation of Banjar care knowledge inherited from their ancestors with various adaptations to the technological, demographic and social status of the Banjar community. Beautiful meaning and beauty care as constructed by Banjar women, cannot be separated from their daily lives in doing activities related to beauty. According to Banjar women, cantic is not as white as the mainstream cantic meaning. Beautiful according to them is clean. The typical series of beauty treatments from Banjar is timung. Before the turtle is carried out, the women first do scrub treatment. as a result of the fumigation of the body from the vapor of the ingredients used for timung. canti is white. Even though it's white if it's not clean, it doesn't look fancy. But if the brown skin is mature but clean it will look cantic. The construction of the beauty of Banjar women which is built from many aspects that influence it raises the concept that beauty is clean.

With social construction thinking about the culture of beauty care for Banjar women, the emergence of this shift in culture is a natural phenomenon as a form of human dialectics with its social and cultural environment. Therefore, the shift in beauty care culture can be understood as a form of human adaptation to respond to various changes that occur in the community.

\subsection{Shifting in Beauty Care for Banjar Women}

Banjar women's beauty treatments have experienced various shifts. These shifts were found in some elements of the culture of beauty care as described below.

\subsubsection{Beauty Institution}

The beauty treatment process in Banjar is usually carried out in women's homes that will carry out beauty treatments especially for bathing and scrubbing activities. Banjar women 
who will do beauty treatments usually they will call a repairman who usually also has expertise in scrubbing and bathing or a beauty nurse who specializes in beauty treatments. Now there has been a shift in the care of Banjar women's activities in beauty treatments that were originally carried out in women's homes that will carry out treatment or in the workshops, now many have been done in beauty houses that offer a variety of body care services such as scrubs, batimung, hundred, and various other body treatments. Shifting culture of banjar women's beauty care is caused by changes in the social and economic status of Banjar women. The Banjar community is one of the dynamic ethnic groups and is wellknown as an ethnic trader accompanied by the strategic position of the city, making the Banjar people have experienced an increase in their socioeconomic status. Increased income earned by Banjar families has improved their economic status and resulted in an increase in their education and their social status within the Banjar community. Increasing the socioeconomic status of the banjar community has changed the way they care for beauty, which initially carried out beauty treatments in their own homes by bringing beauty care workers who are usually in the form of scrubs and weeds by visiting a number of beauty houses in Banjarmasin with more complete treatment besides their scrub treatments and their bathing is also spoiled with various other treatments such as hundred, paddikur, mannikur, creambath and others. The increasing number of women doing beauty treatments in beauty homes has triggered the flourishing of beauty houses in the city of Banjaramsin. Hampers throughout the city of Banjarmasin are flooded with the rise of beauty houses.

\subsubsection{Materials for Beauty Care}

The ingredients used for the care of the female body of banjar also experienced a shift that was originally the materials used were ingredients made by the beauty care practitioners using materials that were very simple. Along with the development of beauty houses, then the demand for ingredients used for beauty care activities in beauty homes is increasing. Conditions such as encouraging some beauty homes to produce their own beauty care ingredients, not only for the sake of their beauty houses but also for being widely marketed and marketed widely, especially for other beauty houses in Banjarmasin. Beauty care ingredients make Banjar women, now use more ingredients in the market than they make themselves at home so that almost all beauty treatments use ingredients purchased in markets in Banjarmasin.

\subsubsection{The Concept of Beauty}

Wiasti (2010) revealed that the concept of female beauty, from time to time the construction of beauty always underwent changes, ranging from mere sexual to political to socalled dialectics of beauty construction. The ever-changing dialectics of beauty construction can be seen from the different definitions of beauty from time to time. In ancient Greece, the beautiful meaning was naked women. During the 19th century Renaissance, beautiful were aristocratic women, and in the 20th century, the conception of women's beauty was based on ethnic and racial backgrounds, and must be feminine. While the construction of body beauty in this decade is referring to the reference to freshness, leading to something smooth, neat, all of which shifts towards the fresh. Banjar women experienced a shift in beautiful meaning that was once a beautiful female figure portrayed as a woman who had white skin and curly hair shifted into a woman who had clean and radiant skin even some who spread brown color and 
straight hair. This shift in the meaning of beauty can be seen from the various materials used by banjar women who use more materials used to clean the skin so that it looks shiny. Unlike before, whitening products dominated the use of beauty treatments. This condition is also fueled by the many side effects of using ingredients for body whitening (especially), which often results in damage to the skin in the form of black stains or spots that often grow in the face due to whitening side effects.

\section{Conclusion}

Beauty and Banjar women are two things that cannot be released because beauty is the expression and existence of Banjar women in their social environment. Therefore the culture of beauty care is a culture that has an important meaning for Banjar women so that all Banjar women of all social status pay close attention to beauty care. According to the women of Banjar is not a clean is white as it is circulating in today's society. is a concept that occurs from various aspects that affect people's thinking so that it becomes knowledge that is realized in social reality. The entry of technology and modernization in the era of globalization has had an impact on the occurrence of shifts in social cultural beauty care. The emergence of a social cultural shift in Banjar women's beauty care is actually a form of their adaptation to various cultural and social changes around them. The shifts that occur in Banjar women's beauty care are the beauty institutions, the materials used and the concept of beauty. However, the existence of beauty treatments never fades for Banjar women and is always carried out by those who are carried out according to their level of economic ability.

\section{References}

Daud, Alfani, 1997, Islam dan Masyarakat Banjar: Deskripsi dan Analisa Kebudayaan Banjar, Jakarta: PT. Grafindo Persada.

Berger, Peter L., and Luckman, Thomas, 1990, Tafsir Sosial Atas Kenyataan: Risalah tentang Sosiologi Pengetahuan, Terjemahan: Hasan Basari, Jakarta: LP3ES.

Bogdan, Robert, C., dan Biklen, Sari Knopp, 1990, Riset Kualitatif Untuk Pendidikan: Pengantar ke Teori dan Metode, Jakarta: Departemen Pendidikan dan Kebudayaan.

Hammersley, Martyn, and Atkinson, Paul, 1995, Ethnograpy: Principles in Practise, London and New York: Routledge.

Koentjaraningrat, 1990, Pengantar Ilmu Antropologi, Jakarta: PT. Rineka Cipta.

Poloma, Margareth, M., 2003 Sosiologi Kontemporer, Terjemahan: Tim Penerjemah Yasogama, Jakarta: PT. Rajagrafindo Persada.

Reischer, Erica and Koo, Kathryn S., 2004.The Body Beatiful: Symbolism and Agency in the SosialWorld. Annual Review of Anthropology; 2004; ProQuest Sociology.

Spradley, James. P, 1997, Metode Etnografi, Terjemahan: Misbah Zulfa E., Yogyakarta: PT. Tiara Wacana Yogya.

Wiasti, Ni Made, 2010. Redefinisi Kecantikan Dalam Meningkatkan Produktivitas Kerja Perempuan Bali,di Kota Denpasar, Piramida: Jurnal Kependudukan dan Pengembangan Sumber Daya Manusia, Edisi 15 Tahun 2010.

Zeitlin, Irving M., 1995, Memahami Kembali Sosiologi: Kritik Terhadap Teori Sosiologi Kontemporer, Terjemahan: Anshori dan Juhanda, Yogyakarta: Gadjah Mada University Press. 